\title{
Adjuvants Affect Duckweed (Lemna minor) Control with Pelargonic Acid
}

\author{
Charles L. Webber III ${ }^{1}$, James W. Shrefler ${ }^{2} \&$ Merritt J. Taylor ${ }^{3}$ \\ ${ }^{1}$ USDA, Agriculture Research Service, Sugarcane Research Unit, Houma, Louisiana, USA \\ ${ }^{2}$ Cooperative Extension Service, Division of Agriculture Sciences and Natural Resources, Oklahoma State \\ University, Durant, Oklahoma, USA \\ ${ }^{3}$ Department of Agricultural Economics, Division of Agriculture Sciences and Natural Resources, Oklahoma \\ State University, Durant, Oklahoma, USA \\ Correspondence: Charles L. Webber III, USDA, Agriculture Research Service, Sugarcane Research Unit, \\ Houma, LA 70360, USA. Tel: 1-985-226-9705. E-mail: chuck.webber@ars.usda.gov
}

Received: August 13, 2014 Accepted: September 15, 2014 Online Published: November 15, 2014

doi:10.5539/jas.v6n12p1 URL: http://dx.doi.org/10.5539/jas.v6n12p1

\begin{abstract}
Duckweeds (Lemna spp.) are small, free floating aquatic plants that flourish on stagnant or slow moving water surfaces throughout the world. Members of the genus are among the smallest flowering plants, providing food for fish and fowl, but their aggressive growth and invasive tendencies make them formidable aquatic weeds, which when uncontrolled can result in oxygen depletion, fish kills, and death of submerged aquatic plants. Pelargonic acid is a fatty acid naturally occurring in many plants and animals, and present in many foods. $\operatorname{AXXE}^{\circledR}(65 \%$ pelargonic acid, BioSafe Systems LLC) is a potential organic herbicide. Research was conducted to determine the impact of spray adjuvants on duckweed control with pelargonic acid. Duckweed was sprayed with 7 pelargonic acid concentrations $(0,1,2,4,6,8$, and $10 \% \mathrm{v} / \mathrm{v})$ combined with 1 of 3 adjuvant treatments [control, BioLink (30\% garlic extracts, $10 \%$ yucca extracts, and $60 \%$ water) at $0.5 \% \mathrm{v}: \mathrm{v}$, and orange oil $(90 \%$ d'limonene and $10 \%$ inert ingredients) at $0.5 \% \mathrm{v}: \mathrm{v})]$. Visual ratings, measuring percentage duckweed control (percentage dead), were collected at $1,2,3,4,5,6,7,8,9,10$ and 11 days after treatment (DAT). The experiment was conductive twice using 5 replications. Pelargonic acid phytotoxicity increased as spray concentration increased whether an adjuvant was used or not. The $6 \%$ pelargonic acid concentration resulted in $90 \%$ or greater duckweed control for all adjuvant treatments (control, BioLink, and Orange Oil) across all evaluation dates ( $1-11$ DAT). The addition of either adjuvant applied at the $6 \%$ pelargonic acid concentration produced consistently greater duckweed control across all evaluation dates (1 - 11 DAT) compared to the control (no adjuvant). The $8 \%$ pelargonic acid rate produced excellent $(97 \%$ or greater) duckweed control for all adjuvant treatments, with consistently better control with the BioLink adjuvant and typically with the orange oil, compared to the control. At the $10 \%$ rate all treatments provided outstanding ( $99 \%$ or greater) control at all evaluation dates, with no significant differences among adjuvant treatments. The research demonstrated the effectiveness of pelargonic acid in controlling duckweed when applied over-the-top. The addition of the BioLink adjuvant often increased the duckweed control compared to the control (no adjuvant). The authors suggest that further research should investigate whether higher rates of these adjuvants or the use other adjuvants would provide satisfactory duckweed control at lower pelargonic acid application rates and the economic implications of the changes.
\end{abstract}

Keywords: adjuvants, application methods, aquatic weed control, herbicide concentration, Lemna minor, pelargonic acid, pestiphytology, weed control

\section{Introduction}

\subsection{Duckweeds Rapid Growth}

Duckweeds (Lemna spp. L.) are small, free floating aquatic plants that flourish on stagnant or slow moving water surfaces throughout the world. Members of the genus are among the smallest flowering plants and have rapid population growth rates. Duckweed is a natural food source for fish and fowl and is invasive because it is easily transported to new locations by transient water fowl where it quickly exploits suitable environments. Rapid 
vegetative reproduction allows duckweed to double in mass in less than two days and it is capable of producing up to 10 generations from a single frond during a 10 day to 14 day period (Skillicorn et al., 1993).

\subsection{Duckweed Uses}

In addition to its rapid growth, duckweed contains a high quanitity of high quality of proteins, amino acids, minerals, and nutrients (Skillicorn et al., 1993). Researchers have demonstrated the beneficial aspects of using duckweed for domestic fish production (Arrivillage, 1994; Essa, 1997; Fasakin et al., 1999; Leng et al., 1995; Robinette et al., 1980; Skillicorn et al., 1993; Van Dyke \& Sutton, 1977), including catfish, tilapia and carp, domestic birds, including ducks (Hossain, 1998; Khanum et al., 2005; Leng et al., 1995; Muztar et al., 1979) and chickens (Abdulayef, 1969; Haustein et al., 1988, 1992, 1994; Lautner \& Mueller, 1954; Muzaffarov et al., 1968; Muztar et al., 1979; Truax et al., 1972;), pigs (Landolt \& Kandeler, 1987; Leng et al., 1995), and ruminants (Leng et al., 1995; Smith \& Leng, 1993), including cattle (Rusoff et al., 1978, 1980), sheep (Porath et al., 1986), and goats (Reid, 2003). These studies have shown that duckweed can provide a large portion of the protein content, and in some cases, the entire protein requirements of certain animals. The extent at which duckweed can provide the nutritional needs of animals depends on the specific animal's growth stage and nutritional requirements, and the conditions under which the duckweed is produced (Culley et al., 1981; Leng et al., 1995; Skillicorn et al., 1993).

One method of obtaining large quantities of nutrient rich duckweed biomass are commercial sustainable production systems based on waste water, either animal or human (Körner et al., 2003). Duckweed is ideally suited to clean waste water (Alaerts et al., 1996; Hammouda et al., 1995; Körner et al., 1998, 2003; Mandi, 1994; Skillicorn et al., 1993), because of its efficient nutrient absorption (Ice \& Couch, 1987), its rapid growth rate (Skillicorn et al., 1993), and its ease of harvest (Körner et al., 2003), while providing not only a nutrient rich duckweed biomass for animal feeds, but an alternative feed stock source for biofuels (Cheng \& Stomp, 2009). Use of duckweed biomass for biofuel production also avoids safety concerns about the direct human consumption of animals raised on waste water grown duckweed (Cheng \& Stomp, 2009).

\subsection{Duckweed Control}

Unfortunately, duckweed's aggressive growth, ability to compete, and invasive tendencies make it a formidable aquatic weed, which uncontrolled, can result in oxygen depletion, decreased fish production, fish kills, reduced plant diversity, and decreases in aesthetics and navigation (Parr et al., 2002; Meijer \& Sutton, 1987). Diquat (1,1'-ethylene-2,2'-dipyridylium) and fluridone [(1-methyl-3-phenyl-5-[3-trifluoromethyl) phenyl]-4(1H)-pyridinone)] are two synthetic (non-organic) aquatic herbicides recommended for duckweed control (Arnold, 1979; Blackburn \& Weldon, 1965; Cheshier et al., 2008; Langeland et al., 2002; McCowen et al., 1979; Wells et al., 1986). Diquat and fluridone, like the other synthetic herbicides, have advantages and disadvantages when attempting to control duckweed, but are not approved where the water would be used for certified organic crop production. One important aspect of certified organic crop production is prevention of non-organic substances from entering into the production area. This would include the intentional application of irrigation water, or natural water flow, containing disallowed material, from a pond or lake onto a certified organic production area.

\subsection{Duckweed Control with Pelargonic Acid}

Pelargonic acid is a fatty acid naturally occurring in many plants and animals and present in many foods (EPA, 2004). Pelargonic acid injures and kills plants by cell membrane disruption, thereby causing rapid desiccation of plant tissues. Chloroplast bleaching is seen within a short time after application (Senseman, 2007). Although the exact mode of action is not yet known, the primary impact is the immediate decrease in intercellular $\mathrm{pH}$ with a resulting loss of cell membrane integrity (Senseman, 2007). Pelargonic acid has potential as an organic non-selective postemergent contact herbicide for terrestrial weeds (Webber et al., 2005; Webber \& Shrefler, 2007; Webber et al., 2014). Pelargonic acid provided excellent weed control at low application rates and volumes in the terrestrial environment. In addition to pelargonic acid, other fatty acids are under consideration and development as potential organic herbicides.

Webber (2009) determined that pelargonic acid was phytotoxic to duckweed when placed in the water in which the duckweed was growing. Webber (2009) achieved $99 \%$ or greater control at 3 days after treatment (DAT) when the pelargonic acid concentration reached $0.00975 \% \mathrm{v} / \mathrm{v}$. C. L. Webber and D. M. Webber (2011) determined that an over-the-top application of pelargonic acid would also control duckweed at $99 \%$ or greater level at 5 DAT with a 4\% v/v application rate. Taylor et al. (2014) determined that the over-the-top method of application of pelargonic acid was the application method of choice due to its greater flexibility and cost effectiveness. When comparing the two application methods, Taylor et al. (2014) determined it would cost 65 
times more to control duckweed at the $99 \%$ level when placing the pelargonic acid in solution (assuming a water depth of $1 \mathrm{~m}$ ) compared to the over-the-top method. The over-the-top method was also seen as a more strategic method of control, providing selective and/partial control of sections of water. The research demonstrated the effectiveness of pelargonic acid in controlling duckweed when applied over-the-top, resulting in a more precise, environmentally targeted, and cost effective duckweed control method than when placing the pelargonic acid in the water itself. Taylor et al. (2014) also suggested further research should address the impact of application volumes and adjuvants on duckweed control and costs. Adjuvants are added to herbicide spray mixtures to improve or modify the physical properties or chemical action of the herbicide mixture (Hazen, 2000). Research was conducted to determine the impact of spray adjuvants on duckweed control with pelargonic acid.

\section{Materials and Methods}

\subsection{Duckweed Production and Pelargonic Acid Applications}

Duckweed (Lemna minor L.) was grown in $9 \mathrm{~L}$ aquatic growth chambers in a greenhouse at Lane, OK. Duckweed, $2.6 \mathrm{~g}$ fresh weight, was transferred from the established greenhouse populations to $400 \mathrm{~mL}$ beakers containing $300 \mathrm{~mL}$ of water and placed in a greenhouse. The plant material uniformly covered the water surface of each beaker. The beakers with the duckweed plants were allowed to stabilize for 6 days. Treatments were prepared using $\operatorname{AXXE}^{\circledR}$ (Note 1 and Note 2) (65\% pelargonic acid, BioSafe Systems LLC), a potential organic herbicide under development for terrestrial weed control, and 3 adjuvant treatments [BioLink Surfactant \& Penetrant ${ }^{\circledR}$ (Note 3) (Westbridge, Vista, California), Orange Oil (Note 4) (Nature's Guide, Fort Worth, Texas) and a control (no adjuvant added)]. BioLink ${ }^{\circledR}$ is an OMRI ${ }^{\mathrm{TM}}$ (Note 5) listed, organically approved adjuvant that is low foaming, non-ionic type spreader, which is $30 \%$ yucca extracts, $10 \%$ garlic extracts, and $60 \%$ water. Nature's Guide Orange $\mathrm{Oil}^{\mathrm{TM}}$ is $90 \%$ d'limonene and $10 \%$ inert ingredients. The randomized complete design included 7 pelargonic acid concentrations $(0,1,2,4,6,8$, and $10 \% \mathrm{v} / \mathrm{v})$ that were combined with 1 of 3 adjuvant treatments [control (no adjuvant), BioLink (0.5\% v:v), and Orange Oil (0.5\% v:v)] applied with a $\mathrm{CO}_{2}$ sprayer equipped with an extended range, stainless steel, $1.51 \mathrm{~L} \mathrm{~min}^{-1}$ nozzle (XR TeeJet ${ }^{\mathbb{B}}$, XR8004, Spraying Systems Co., Wheaton, Illinois) at an application volume of $374 \mathrm{~L} \mathrm{ha}^{-1}$ at 2.75 bars. The experiment was conducted twice using 5 replications.

\subsection{Data Collection}

Visual ratings, measuring percentage duckweed control (percentage dead), were collected at daily 1 through 11 days after treatment (DAT). All data were subjected to ANOVA and mean separation using LSD with $\mathrm{P}=0.05$ (SAS Inc., SAS, Ver. 9.0, Cary, NC). The percentage of duckweed control was prepared for analyses using a square root arcsine transformation to normalize the data. Mean differences were determined using the transformed data and the non-transformed data values are reported using the mean differences determined with the transformed data.

\section{Results and Discussion}

\subsection{Statistical Analysis}

Statistical analysis determined that there were no significant interaction within experiments or combined across experiments, therefore the application rate and adjuvant treatments will be discussed averaged across experiments (Table 1).

\subsection{1\% Pelargonic Application Rate}

Pelargonic acid phytotoxicity increased as spray concentration increased whether an adjuvant was used or not (Table 1). Although BioLink provided a slight benefit to duckweed control when observed at 1 and 2 DAT at the $1 \% \mathrm{v} / \mathrm{v}$ pelargonic acid concentration, the duckweed control level was so low, 6.6 and $7.95 \%$ control, respectively, the difference resulted in little practical advantage and there was no control differences at the $1 \%$ concentration after 2 DAT (Table 1).

\section{$3.32 \%$ Pelargonic Application Rate}

At the $2 \%$ pelargonic acid concentration, where initial duckweed control ranged from 32.8 and $51.5 \%$ (1 DAT), neither adjuvant provided a clear benefit in controlling duckweed compared to the no adjuvant control and provided less control after 7 DAT. In fact, the BioLink treatment at the $2 \%$ pelargonic concentration had consistently lower duckweed control for all the rating times (1 - 11 DAT) than using no adjuvant (Table 1).

\subsection{4\% Pelargonic Application Rate}

The $4 \%$ pelargonic application rate appears to be a transitional rate between the low duckweed control at the $2 \%$ pelargonic rate and the consistently higher control at the $6 \%$ pelargonic concentrations. No differences were 
observed among the adjuvant treatments for the 4\% PA concentrations, but there was a steep decrease from the initial weed control ratings at 1 DAT, averaging $91 \%$ control, to an average $66 \%$ control at 11 DAT.

\section{$3.56 \%$ Pelargonic Application Rate}

The $6 \%$ pelargonic acid concentration resulted in $90 \%$ or greater duckweed control for all adjuvant treatments (control, BioLink, and Orange Oil) across all evaluation dates (1 DAT - 11 DAT). The addition of either adjuvant applied at the $6 \%$ pelargonic acid concentration produced consistently greater duckweed control across all evaluation dates (1 DAT - 11 DAT) compared to the control (no adjuvant). The initial (1 DAT) duckweed control for the adjuvants averaged 97\% (3\% greater than the control) with final control (11 DAT) averaging $97 \%$ compared to the $91 \%$ for the control.

\section{$3.68 \%$ and $10 \%$ Pelargonic Application Rate}

The $8 \%$ pelargonic acid rate produced excellent (97\% or greater) duckweed control for all adjuvant treatments, with consistently better control with the BioLink adjuvant and typically with the orange oil, compared to the control. At the $10 \%$ rate all treatments provided outstanding (99\% or greater) control at all evaluation dates, with no significant differences among adjuvant treatments. 
Table 1 . The phytotoxicity of pelargonic acid concentrations (0 to $10 \%)$ and adjuvant treatments (control, BioLink, and Orange Oil) applied over-the-top on duckweed averaged across two experiments for weed control ratings for 1 to 11 days after treatments (DAT)

\begin{tabular}{|c|c|c|c|c|c|c|c|c|c|c|c|c|}
\hline \multirow{2}{*}{$\begin{array}{c}\text { Pelargonic } \\
\text { Acid }^{\mathrm{z}}\end{array}$} & \multirow[b]{2}{*}{ Adjuvant } & \multicolumn{11}{|c|}{ Days After Treatment (DAT) } \\
\hline & & 1 & 2 & 3 & 4 & 5 & 6 & 7 & 8 & 9 & 10 & 11 \\
\hline$\%$ & & $\%$ & $\%$ & $\%$ & $\%$ & $\%$ & $\%$ & $\%$ & $\%$ & $\%$ & $\%$ & $\%$ \\
\hline 0 & Control $^{\mathrm{y}}$ & $0 \mathrm{~ns}$ & $0 \mathrm{~ns}$ & $0 \mathrm{~ns}$ & $0 \mathrm{~ns}$ & $0 \mathrm{~ns}$ & $0 \mathrm{~ns}$ & $0 \mathrm{~ns}$ & $0 \mathrm{~ns}$ & $0 \mathrm{~ns}$ & $0 \mathrm{~ns}$ & $0 \mathrm{~ns}$ \\
\hline 0 & BioLink $^{x}$ & $0 \mathrm{~ns}$ & $0 \mathrm{~ns}$ & $0 \mathrm{~ns}$ & $0 \mathrm{~ns}$ & $0 \mathrm{~ns}$ & $0 \mathrm{~ns}$ & $0 \mathrm{~ns}$ & $0 \mathrm{~ns}$ & $0 \mathrm{~ns}$ & $0 \mathrm{~ns}$ & $0 \mathrm{~ns}$ \\
\hline 0 & Orange $\mathrm{Oil}^{\mathrm{w}}$ & $0 \mathrm{~ns}$ & $0 \mathrm{~ns}$ & $0 \mathrm{~ns}$ & $0 \mathrm{~ns}$ & Ons & $0 \mathrm{~ns}$ & $0 \mathrm{~ns}$ & $0 \mathrm{~ns}$ & $0 \mathrm{~ns}$ & $0 \mathrm{~ns}$ & $0 \mathrm{~ns}$ \\
\hline 1 & Control & $3 b^{v}$ & $3 \mathrm{~b}$ & $3 \mathrm{~ns}$ & $3 \mathrm{~ns}$ & $3 \mathrm{~ns}$ & $2 \mathrm{~ns}$ & $2 \mathrm{~ns}$ & $2 \mathrm{~ns}$ & $2 \mathrm{~ns}$ & $2 \mathrm{~ns}$ & $2 \mathrm{~ns}$ \\
\hline 1 & BioLink & $7 \mathrm{a}$ & $8 \mathrm{a}$ & $8 \mathrm{~ns}$ & $9 \mathrm{~ns}$ & $8 \mathrm{~ns}$ & $8 \mathrm{~ns}$ & $7 \mathrm{~ns}$ & $6 \mathrm{~ns}$ & $5 \mathrm{~ns}$ & $4 \mathrm{~ns}$ & $3 \mathrm{~ns}$ \\
\hline 1 & Orange Oil & $4 \mathrm{~b}$ & $4 \mathrm{ab}$ & $5 \mathrm{~ns}$ & $5 \mathrm{~ns}$ & $4 \mathrm{~ns}$ & $3 \mathrm{~ns}$ & $2 \mathrm{~ns}$ & $2 \mathrm{~ns}$ & $2 \mathrm{~ns}$ & $2 \mathrm{~ns}$ & $2 \mathrm{~ns}$ \\
\hline 2 & Control & $49 a$ & $51 \mathrm{a}$ & $51 \mathrm{a}$ & $49 \mathrm{a}$ & $46 \mathrm{a}$ & $43 \mathrm{a}$ & $41 \mathrm{a}$ & $40 \mathrm{a}$ & $40 \mathrm{a}$ & $39 a$ & $39 a$ \\
\hline 2 & BioLink & $33 \mathrm{~b}$ & $33 \mathrm{~b}$ & $33 \mathrm{~b}$ & $32 \mathrm{~b}$ & $30 \mathrm{~b}$ & $28 \mathrm{~b}$ & $26 \mathrm{~b}$ & $26 \mathrm{c}$ & $26 \mathrm{~b}$ & $27 \mathrm{~b}$ & $28 \mathrm{~b}$ \\
\hline 2 & Orange Oil & $52 \mathrm{a}$ & $52 \mathrm{a}$ & $50 \mathrm{a}$ & $47 \mathrm{a}$ & $42 \mathrm{a}$ & $36 \mathrm{a}$ & $33 \mathrm{~b}$ & $32 \mathrm{~b}$ & $31 \mathrm{~b}$ & $31 \mathrm{~b}$ & $30 \mathrm{~b}$ \\
\hline 4 & Control & $91 \mathrm{~ns}$ & $84 \mathrm{~ns}$ & $83 \mathrm{~ns}$ & $81 \mathrm{~ns}$ & $73 \mathrm{~ns}$ & $65 \mathrm{~ns}$ & $64 \mathrm{~ns}$ & $63 \mathrm{~ns}$ & $62 \mathrm{~ns}$ & $62 \mathrm{~ns}$ & $62 \mathrm{~ns}$ \\
\hline 4 & BioLink & $93 \mathrm{~ns}$ & $92 \mathrm{~ns}$ & $91 \mathrm{~ns}$ & $89 \mathrm{~ns}$ & $81 \mathrm{~ns}$ & $74 \mathrm{~ns}$ & $71 \mathrm{~ns}$ & $68 \mathrm{~ns}$ & $68 \mathrm{~ns}$ & $68 \mathrm{~ns}$ & $68 \mathrm{~ns}$ \\
\hline 4 & Orange Oil & $91 \mathrm{~ns}$ & $93 \mathrm{~ns}$ & $91 \mathrm{~ns}$ & $89 \mathrm{~ns}$ & $83 \mathrm{~ns}$ & $77 \mathrm{~ns}$ & $74 \mathrm{~ns}$ & $71 \mathrm{~ns}$ & $70 \mathrm{~ns}$ & $69 \mathrm{~ns}$ & $69 \mathrm{~ns}$ \\
\hline 6 & Control & $95 \mathrm{~b}$ & $95 \mathrm{~b}$ & $95 \mathrm{~b}$ & $95 \mathrm{~b}$ & $95 \mathrm{~b}$ & $95 \mathrm{~b}$ & $93 \mathrm{~b}$ & $91 \mathrm{~b}$ & $91 \mathrm{~b}$ & $91 \mathrm{~b}$ & $91 \mathrm{~b}$ \\
\hline 6 & BioLink & $97 \mathrm{a}$ & $98 \mathrm{a}$ & $98 \mathrm{a}$ & $98 \mathrm{a}$ & 98 a & $98 \mathrm{a}$ & $98 \mathrm{a}$ & $97 \mathrm{a}$ & $97 \mathrm{a}$ & $97 \mathrm{a}$ & 97 a \\
\hline 6 & Orange Oil & $97 \mathrm{a}$ & $98 \mathrm{a}$ & $98 \mathrm{a}$ & 99 a & 99 a & $98 \mathrm{a}$ & $98 \mathrm{a}$ & $98 \mathrm{a}$ & $98 \mathrm{a}$ & $98 \mathrm{a}$ & $98 \mathrm{a}$ \\
\hline 8 & Control & $97 \mathrm{~b}$ & $98 \mathrm{c}$ & $98 \mathrm{~b}$ & $98 \mathrm{~b}$ & $98 \mathrm{~b}$ & $97 \mathrm{~b}$ & $97 \mathrm{c}$ & $97 \mathrm{c}$ & $97 \mathrm{c}$ & $98 \mathrm{c}$ & $98 \mathrm{c}$ \\
\hline 8 & BioLink & 99 a & $100 \mathrm{a}$ & $100 \mathrm{a}$ & $100 \mathrm{a}$ & $100 \mathrm{a}$ & $100 \mathrm{a}$ & $100 \mathrm{a}$ & $100 \mathrm{a}$ & $100 \mathrm{a}$ & $100 \mathrm{a}$ & $100 \mathrm{a}$ \\
\hline 8 & Orange Oil & $98 \mathrm{~b}$ & $99 \mathrm{~b}$ & 99 a & $99 \mathrm{ab}$ & 99 a & 99 a & $99 \mathrm{~b}$ & $99 \mathrm{~b}$ & $99 \mathrm{~b}$ & $99 \mathrm{~b}$ & $99 \mathrm{~b}$ \\
\hline 10 & Control & $100 \mathrm{~ns}$ & $100 \mathrm{~ns}$ & $100 \mathrm{~ns}$ & $100 \mathrm{~ns}$ & $100 \mathrm{~ns}$ & $100 \mathrm{~ns}$ & $100 \mathrm{~ns}$ & $100 \mathrm{~ns}$ & $100 \mathrm{~ns}$ & $100 \mathrm{~ns}$ & $100 \mathrm{~ns}$ \\
\hline 10 & BioLink & $99 \mathrm{~ns}$ & $99 \mathrm{~ns}$ & $100 \mathrm{~ns}$ & $100 \mathrm{~ns}$ & $99 \mathrm{~ns}$ & $99 \mathrm{~ns}$ & $99 \mathrm{~ns}$ & $99 \mathrm{~ns}$ & $99 \mathrm{~ns}$ & $99 \mathrm{~ns}$ & $100 \mathrm{~ns}$ \\
\hline 10 & Orange Oil & $99 \mathrm{~ns}$ & $100 \mathrm{~ns}$ & $100 \mathrm{~ns}$ & $100 \mathrm{~ns}$ & $100 \mathrm{~ns}$ & $100 \mathrm{~ns}$ & $100 \mathrm{~ns}$ & $100 \mathrm{~ns}$ & $100 \mathrm{~ns}$ & $100 \mathrm{~ns}$ & $100 \mathrm{~ns}$ \\
\hline
\end{tabular}

DAT - days after treatment.

ns - Values followed by ns are not significantly different from the values within the same pelargonic application rate and rating period.

${ }^{\mathrm{z}}$ Pelargonic Acid $=$ Concentration of pelargonic acid in the spray solution applied using $\mathrm{AXXE}^{\circledR}(65 \%$ pelargonic acid, BioSafe Systems LLC) applied with a $\mathrm{CO}_{2}$ sprayer equipped with an extended range, stainless steel, $1.51 \mathrm{~L} \mathrm{~min}^{-1}$ nozzle (XR TeeJet ${ }^{\mathbb{R}}$, XR8004, Spraying Systems Co., Wheaton, Illinois) at an application volume of $374 \mathrm{~L} \mathrm{ha}^{-1}$ at 2.75 bars.

${ }^{\mathrm{y}}$ Control $=$ Adjuvant treatment where no adjuvant was added to the spray solution.

${ }^{\mathrm{x}}$ BioLink $=$ Adjuvant treatment were BioLink Surfactant $\&$ Penetrant ${ }^{\circledR}$, Westbridge, Vista, California, was added to spray solution at $0.5 \% \mathrm{v}: \mathrm{v}$ ( $30 \%$ yucca extracts, $10 \%$ garlic extracts, and $60 \%$ water).

${ }^{\mathrm{w}}$ Orange Oil = Adjuvant treatment where Orange Oil, Nature's Guide, Fort Worth, Texas, was added to the spray solution at $0.5 \% \mathrm{v} ; \mathrm{v}(90 \% \mathrm{~d}$ 'limonene and $10 \%$ inert ingredients).

${ }^{\mathrm{v}}$ Values in columns within each pelargonic acid application rate followed by the same lower case letter are not significantly different at $\mathrm{P} \leq 0.05$, ANOVA. 


\section{Conclusions}

The research demonstrated the effectiveness of pelargonic acid in controlling duckweed when applied over-the-top and BioLink often improved control. The authors suggest that further research should investigate whether higher rates of these adjuvants or the use other adjuvants would provide satisfactory duckweed control at lower pelargonic acid application rates and the economic implications of the changes.

\section{Acknowlegements}

The authors would like to thank Dr. Vijay Choppakatla, Director of Research, BioSafe Systems LLC, for providing the AXXE and Otis (Buddy) Faulkenberry and Michael Mobbs for maintaining duckweed populations.

\section{References}

Abdulayef, D. A. (1969). The use of common duckweed as green feed for chickens. Uzbekskii Biologicheskii Zournal (USSR), 13(3), 42-43.

Alaerts, G. J., Rahman, M. M., \& Kelderman, P. (1996). Performance analysis of a full-scale duckweed covered lagoon. Water Res., 30, 843-852.

Arnold, W. (1979). Fluridone - A new aquatic herbicide. J. Aquat. Plant Manage., 17, 30-33.

Arrivillage, A. (1994). Effect of substituting prepared feed by the aquatic plant Wolffia sp. (Lemnaceae) on the growth response of tilapia (Oreochromis niloticus) and mojarra paleta (Cichlasoma synspillum) fry. World Aquaculture Soc. Ann. Meeting, Jan. 14-18, 1994. New Orleans, LA, USA.

Blackburn, R. D., \& Weldon, L. W. (1965). The sensitivity of duckweeds (Lemnaceae) and azolla to diquat and paraquat. Weeds, 13, 147-149.

Cheng, J. J., \& Stomp, A. M. (2009). Growing duckweed to recover nutrients from wastewaters and for production of fuel ethanol and animal feed. Clean Soil Air Water, 37(1), 17-26. http://dx.doi.org/10.1002/clen.200800210

Cheshier, J. C., Wersal, R. M., \& Madsen, J. D. (2008). Duckweed control using Fluridone in sequential treatments (pp. 1-6). Mississippi State Univ: GeoResources Institute Rep. 4005.

Culley, Jr., D. D., Rejmankova, E., Kvet, J., \& Frye, J. B. (1981). Production, chemical quality, and use of duckweed (Lemnaceae) in aquaculture, waste management, and animal feeds. J. World Maric. Soc., 12, 27-49. http://dx.doi.org/10.1111/j.1749-7345.1981.tb00273

EPA. (2009). Pesticides: Regulating Pesticides. Pelargonic Acid (217500). U.S. Environmental Protection $\begin{array}{lllll}\text { Agency. } & \text { Retrieved } & \text { September } & 30, & \text { 2009, }\end{array}$ http://www.epa.gov/pesticides/biopesticides/ingredients/factsheets/factsheet_217500.htm

Essa, M. A. (1997). Utilization of some aquatic plants in diets for Nile tilapia, Oreochromis niloticus, fingerlings. Egyp. J. Aquat. Bio. Fish, 1(2), 19-34.

Fasakin, E. A., Balogun, A. M., \& Fasuru, B. E. (1999). Use of duckweed, Spirodela polyrrhiza L. Schleiden, as a protein feedstuff in practical diets for tilapia, Oreochromis niloticus L. Aguacult. Res., 30, 313-318. http://dx.doi.org/10.1046/j.1365-2109.1999.00318.x

Hammouda, O., Gaber, A., \& Abdel-Hameed, M. S. (1995). Assessment of the effectiveness of treatment of waste water-contaminated aquatic systems with Lemna gibba. Enzyme Microb. Technol., 17, 317-323.

Haustein, A. T., Gillman, R. H., Skillicorn, P. W., Hannan, H., Dias, F., Guevana, V., ... Gillman, J. B. (1994). Performance of broiler chickens fed diets containing duckweed (Lemna gibba). J. of Agric. Sci., 122(2), 288-289.

Haustein, A. T., Gillman, R. H., Skillicorn, P. W., Vergara, V., Guevara, V., \& Gastanaduy, A. (1988). Duckweed, a useful strategy for feeding chickens: Performance of layers fed with sewage-grown Lemnaceae species. Poultry Sci., 69, 1835-1844.

Haustein, A. T., Gillman, R. H., Skillicorn, P. W., Vergara, V., Guevara, V., Gastanaduy, A., \& Gillman, J. B. (1992). Compensatory growth in broiler chicks fed on Lemna gibba. British J. Nutrition, 68(2), 329-335. http://dx.doi.org/10.1017/S0021859600087475

Hazen, J. L. (2000). Adjuvants-terminology, classification, and chemistry. Weed Technology, 14, 773-784. http://dx.doi.org/10.1614/0890-037X(2000)014[0773:ATCAC]2.0.CO;2 
Hossain, M. J. (1998). Use of duckweed as a feed for ducks. Duckweed production by using integrated farm waste and its utilization as animal feed (pp. 21-23). A publication of Duckweed Research Project, Ministry of Fisheries and Livestock and BLRI, Bangladesh.

Ice, J., \& Couch, R. (1987). Nutrient absorption by duckweed. J. Aquat. Plant Manage., 25, 30-31.

Khanum, J., Chwalibog, A., \& Huque, K. S. (2005). Study on digestibility and feeding systems of duckweed in growing ducks. Livestock Research for Rural Development, 17, 1-10.

Körner, S., Lyatuu, G. B., \& Vermaat, J. E. (1998). The influence of Lemna gibba L. on the degradation of organic material in duck-weed covered domestic waste water. Water Res., 32, 3092-3098.

Körner, S., Vermaat, J. E., \& Veenstra, S. (2003). The capacity of duckweed to treat wastewater. J. Environ. Qual., 32, 1583-1590.

Landolt, E., \& Kandeler, R. (1987). The family of Lemnaceae - a monographic study (Vol. 2). Phytochemistry, physiology; application; bibliography, Ver_ffentlichungen des Geobotanischen Institutes ETH, Stiftung Rubel, Zurich, Switzerland.

Langeland, K. A., Hill, O. N., Koschnick, T. J., \& Haller, W. T. (2002). Evaluation of a new formulation of Reward Landscape and Aquatic Herbicide for control of duckweed, waterhyacinth, waterlettuce, and hydrilla. J. Aquat. Plant Manage., 40, 51-53.

Lautner, V., \& Mueller, Z. (1954). Feeding value of some water plants I. Abornik Cesk. Akad. Zemedl, 27(A), 333-354.

Leng, R. A., Stanbolie, J. H., \& Bell, R. (1995). Duckweed - a potential high-protein feed resource for domestic animals and fish. Livestock Research for Rural Development, 7(1), 11. Retrieved September 30, 2009, from http://www.lrrd.org/lrrd7/1/3.htm

Mandi, L. (1994). Marrakesh waste water purification experiment using vascular aquatic plants Eichhornia crassipes and Lemna gibba. Water Sci. Technol., 29, 283-287.

McCowen, M. C., Young, C. L., West, S. D., Parka, S. J., \& Arnold, W. R. (1979). Fluridone, a new herbicide for aquatic plant management. J. Aquat. Plant Manage., 17, 27-30.

Meijer, L. E., \& Sutton, D. L. (1987). Influence of plant position on growth of duckweed. J. Aquat. Plant Manage., 25, 28-30.

Muzaffarov, A. M., Taubayev, T., \& Abdiyev, M. (1968). The use of Lemna minor L. for poultry feeding. Usbekskii Biologia Cheskii Zournal (USSR), 12(3), 44-46.

Muztar, A. J., Slinger, S. J., \& Burton, J. H. (1979). Metabolizable energy content of freshwater plants in chicken and ducks. Poult. Sci., 56, 1893-1899.

Parr, L. B., Perkins, R. G., \& Mason, C. F. (2002). Reduction in photosynthetic efficiency of Cladophora glomerata, induced by overlying canopies of Lemna spp. Water Res., 36, 1735-1742.

Porath, D., Oron, G., \& Granoth, G. (1986). Duckweed as an aquatic crop: Edible protein recovery, production and utilization (pp. 680-687). Proc. Fifth Int. Symp. Agric. Waste, Amer. Soc. of Agric. Engineers. St. Joseph, MI, USA.

Reid, W. S. (2003). Exploring duckweed (Lemna gibba) as a protein supplement for ruminants using the Boer goat (Capra hircus) as a model. Masters of Science Thesis, North Carolina State Univ., Raleigh, N.C., USA.

Robinette, H. R., Brunson, M. W., \& Day, E. J. (1980). Use of duckweed in diets of channel catfish. Proc.13th Ann. Conf. SE Assoc. Fish Wildlife Age (pp. 108-114).

Rusoff, L. L., Blakeney, E. W., \& Culley, D. D. (1980). Duckweeds (Lemnaceae family) - a potential source of protein and amino acids. J. Agric. Food Chem., 28, 848-850. http://dx.doi.org/10.1021/jf60230a040

Rusoff, L. L., Zeringgue, S. P., Achacoso, A. S., \& Culley, D. D. (1978). Feeding value of duckweed (an aquatic plant, family Lemnaceae) for ruminants. J. Dairy Sci., 61(1), 186.

Senseman, S. A. (2007). Herbicide Handbook (9th ed.). Weed Science Society of America. Lawrence, KS.

Skillicorn, P., Spira, W., \& Journey, W. (1993). Duckweed aquaculture. A New Aquatic Farming System for Developing Countries (p. 76). The World Bank, Washington, DC., USA. Retrieved from http://www.p2pays.org/ref/09/08875.htm 
Smith, P., \& Leng, R. A. (1993). Rural Science Honours thesis "Bypassing Duckweed Protein" UNE. Armidale, NSW, Australia.

Taylor, M. J., Webber III, C. L., \& Webber, D. M. (2014). Economic comparison of two application methods for potential organic control of duckweed utilizing pelargonic acid as an aquatic herbicide. Empirical Econometrics and Quantitative Economics Letters (In Press).

Truax, R. E., Culley, D. D., Griffith, M., Johnson, W. A., \& Wood, J. P. (1972). Duckweed for chick feed? Louisiana Agric., 16(1), 8-9.

Van Dyke, J. M., \& Sutton, D. L. (1977). Digestion of duckweed (Lemna spp.) by the grass carp (Ctenopharyngolon edella). J. Fish Bio., 11, 273-278.

Webber III, C. L. (2009). Pelargonic acid - A potential organic aquatic herbicide for duckweed management. $J$. Environ. Monitor. Restor., 6, 174-180.

Webber III, C. L., \& Shrefler, J. W. (2007). Pelargonic acid weed control: Concentrations, adjuvants, and application timing. Proc. $26^{\text {th }}$ Hort. Industries Show. Ft. Smith, AR. Jan. 5-6, 2007 (pp. 145-148).

Webber III, C. L., \& Webber, D. M. (2011). Duckweed control with over-the-top application of pelargonic acid. J. Environ., Monitor., and Restor., 7, 78-86.

Webber III, C. L., Shrefler, J. W., \& Langston, V. B. (2005). Weed control with pelargonic acid (2004) Lane, Oklahoma. In L. Brandenberger \& L. Wells (Eds.), 2004 Vegetable Weed Control Studies (pp. 32-33). Oklahoma State Univ., Div. of Agric. Sci. and Natural Resources, Depart. of Hort. \& Landscape Architecture. Stillwater, OK. MP-162.

Webber III, C. L., Taylor, M. J., \& Shrefler, J. W. (2014). Weed control in squash (Cucurbita pepo L.) using sequential post-directed applications of pelargonic acid. Hort. Tech., 24(1), 25-29.

Wells, R., Coffey, B., \& Lauren, D. (1986). Evaluation of Fluridone for weed control in New Zealand. J. Aquat. Plant Manage., 24, 39-42.

\section{Notes}

Note 1. The mention of trade names or commercial products in this publication is solely for the purpose of providing specific information and does not imply recommendation or endorsement by the U.S. Department of Agriculture.

Note 2. $\operatorname{AXXE}^{\circledR}$ (65\% pelargonic acid), BioSafe Systems LLC, Meadow Street, East Hartford, CT 06108, Phone: 860.290.8890, Fax: 860.290.8802, Website Address: www.biosafesystems.com

Note 3. BioLink Surfactant \& Penetrant ${ }^{\circledR}(30 \%$ garlic extracts, $10 \%$ yucca extracts, and $60 \%$ water), Westbridge, 1260 Avenida Chesea, Vista, CA, 92081, Phone: 800.876.2767, Website: www.westbridge.com

Note 4. Orange Oil (90\% d'limonene and 10\% inert ingredients), Nature's Guide, P.O. Box 471549 Fort Worth, TX 76147. http://natures-guide.com/Resources/NG\%20Orange\%20Oil\%20Concentrate\%20\%26\%20RTU.pdf

Note 5. OMRI ${ }^{\mathrm{TM}}$ http://www.omri.org/simple-opl-search/results/BioLink

\section{Copyrights}

Copyright for this article is retained by the author(s), with first publication rights granted to the journal.

This is an open-access article distributed under the terms and conditions of the Creative Commons Attribution license (http://creativecommons.org/licenses/by/3.0/). 